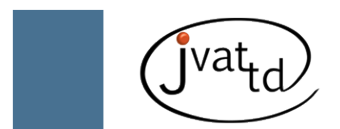

\title{
Butantan Institute: strategies to obtain scorpions for the production of anti-scorpion serum
}

Lucas SM (1), Goldoni PAM (1), Candido DM (1), Knysak I (1)

(1) Arthropod Laboratory, Butantan Institute, São Paulo, São Paulo State, Brazil.

\section{Dear Editor,}

Continuing previous communications on the importance of Butantan Institute to Brazilian science, we would like to report through this letter its initiative on scorpion antivenom production. In 1918, the first director of Butantan Institute, Vital Brazil, exposed at the Second Conference of the South American Society of Hygiene, Microbiology and Pathology the following: "In 1905, the Butantan Institute has begun the study of scorpion venoms. The main problem was the acquisition of material. In fact, where could we get those arachnids in so large quantities? Several times we sent representatives to the state of Minas Gerais with the intention of looking for this material in places where they are common, and the results were every time so meagre that we could not begin the immunization of animals in order to fulfill our intent. At the beginning of 1907, we accidentally met a hunter of those animals, and he could offer us thousands of them. This man was working on empty plots around the city and observed that he could find some scorpions inside termitaries. After this observation, he had the idea of becoming a 'scorpion hunter'. These animals are cannibals and for this reason, we can rarely find more than two in the same shelter. The venom glands are situated in the last tail segment. To prepare the antigen in large quantities we must cut off the segment from live or recently dead animals using a scissor" $(1,2)$.
In 1939, the biologist Wolfgang Bücherl was hired by the Butantan Institute. Shortly after, he became the head of the Laboratory of Medical Zoology and responsible for the supply of scorpion venom. Since 1952, he was involved in the maintenance of scorpions in captivity and, for the first time, he employed the electric method of venom extraction. This represented a progress, since animals were not sacrificed anymore, enabling the extraction of venom from the same scorpion several times. The technique also improved the antigen quality (3).

During the following years, the Institute asked suppliers numerous times to send live scorpions. Bücherl was grateful to many institutions of São Paulo and Minas Gerais states for animal collection. However, the main problem was that during transportation, around 30\% of the collected scorpions died. Additionally, many of them were intoxicated by pesticides.

From 1951 to 1953, Butantan Institute received 1,400 live scorpions, an insufficient amount to ensure the antivenom production. To solve such problem, Felisberto Miguel Arcanjo (from Santa Bárbara de Nova Era, Minas Gerais state) was hired and paid per delivered scorpion; thus, the Institute would have a permanent supply of live animals. The specimens used to be transported for free by the railway company in wooden boxes containing humid pieces of smashed sugar cane.

By the end of 1967, Bücherl had retired. Sylvia Lucas, the new responsible for the 
laboratory, found new hunters such as José Lucas Martins from Córrego Novo (Minas Gerais state). Between 1962 and 1971, Felisberto and José Lucas collected 209,222 live scorpions for the institution. José Lucas sent the last 5,000 scorpions in 1988 and Felisberto finished his collaboration in 1990.

In the 1980s, it became harder to collect a steady stock of scorpions, due to the privatization of most railway companies which collaborated with free transportation of animals, and also as a result of new environmental laws.

In the meantime, the number of registered accidents in São Paulo state was increasing. Among the main causes were urbanization and synantropic habits of Tityus serrulatus $(4,5)$. Another important factor was a new regulation from the Ministry of Health, which required the notification of accidents caused by scorpions. Consequently, the demand for scorpion antivenom (as well as the venom necessary for its production) augmented and new strategies to obtain sufficient scorpions were necessary.

From 1984 to 1986, the laboratory technicians carried out planned capture trips in the surrounding areas of São Paulo city, where the largest number of accidents were registered. Although the results were positive, such method was difficult to maintain for several reasons, including lack of transportation, limited number of professionals and it was hard to access private properties. Anyway, the acquired knowledge on scorpion habits during those capture trips was very rewarding.

From 1990 on, the Institute made the first agreements with city administrations, São Paulo Zoonosis Control Center, and Superintendence for Endemic Disease Control (SUCEN), which started to send scorpions to the laboratory irregularly. Most animals delivered by those institutions were dead, due mainly to longtime transportation, inappropriate cages or pesticides. In 1994, a collaboration among the São Paulo State Secretary of Health, SUCEN, Prof. Alexandre Vranjac Epidemiologic Surveillance Center and the Institute proposed new strategies for activities connected to scorpion control.

Table 1. Arrival of scorpions according to municipality of São Paulo state and year

\begin{tabular}{c|c|c|c|c|c|c|c|c|c|c|c|c}
\hline City Year & 1994 & 1995 & 1996 & 1997 & 1998 & 1999 & 2000 & 2001 & 2002 & 2003 & 2004 & Total \\
\hline Americana & 848 & 2692 & 634 & 574 & 1006 & 1129 & 1060 & 1905 & 1649 & 1648 & 1036 & 14181 \\
\hline Barretos & - & - & - & 116 & - & - & - & - & - & - & - & 116 \\
\hline Franca & 14 & 60 & 123 & - & 337 & - & - & - & - & - & - & 534 \\
\hline Itu & - & - & - & - & - & - & - & 185 & - & - & - & 185 \\
\hline Jaboticabal & - & - & - & - & - & - & - & - & - & - & 330 & 330 \\
\hline Jundiaí & - & - & - & 87 & 23 & - & - & - & - & - & - & 110 \\
\hline Limeira & 533 & 636 & 256 & 169 & 192 & 62 & - & - & - & - & - & 1848 \\
\hline Pindamonhangaba & - & - & - & - & - & - & - & - & - & 388 & 82 & 470 \\
\hline Piracaia & - & 75 & - & - & - & - & - & - & - & - & - & 75 \\
\hline Piracicaba & 58 & 623 & 1756 & 1150 & 878 & 555 & 373 & 122 & 307 & 185 & 857 & 6864 \\
\hline Pompéia & - & - & - & - & 88 & - & - & - & - & - & - & 88 \\
\hline Porto Feliz & - & - & - & - & - & - & - & - & - & - & 48 & 48 \\
\hline Presidente Prudente & 20 & 67 & 45 & 78 & 121 & 84 & - & 84 & 62 & 34 & 160 & 755 \\
\hline Ribeirão Preto & 1388 & 767 & 465 & 836 & 628 & 274 & 523 & 294 & - & 22 & 60 & 5257 \\
\hline $\begin{array}{c}\text { São Bernardo do } \\
\text { Campo }\end{array}$ & - & - & - & 93 & - & - & - & - & - & - & - & 93 \\
\hline $\begin{array}{c}\text { São José do Rio } \\
\text { Pardo }\end{array}$ & - & - & 105 & - & - & - & 56 & - & - & - & - & 161 \\
\hline $\begin{array}{c}\text { São José do Rio } \\
\text { Preto }\end{array}$ & - & 22 & - & - & - & - & - & - & - & - & - & 22 \\
\hline $\begin{array}{c}\text { Sumaré } \\
\text { Total }\end{array}$ & - & - & - & - & - & - & - & - & - & 39 & 84 & 123 \\
\hline \begin{tabular}{c}
2861 \\
\hline
\end{tabular} & 4942 & 3384 & 3103 & 3273 & 2106 & 2012 & 2590 & 2018 & 2316 & 3628 & 32231 \\
\hline
\end{tabular}




\section{FIRST STEPS FOR ACTIVITY COORDINATION}

The beginning of activities was planned in December 1991 by Von Eickstedt, the responsible for the Arthropod Laboratory during the Meeting on "Control and Prevention of Scorpion Accidents in São Paulo State", organized by the Butantan Institute and Permanent Commission on Coordination and Control of Accidents by Poisonous Animals of the São Paulo State Secretary of Health. In this event were reported and discussed the experiences of health professionals from São Paulo state and the responsibilities of official organizations involved with problems related to scorpions. The experience of Lucia A. Taveira, from the Regional Service of Ribeirão Preto (SUCEN), was extremely valuable. She had started a trial experiment in Sertãozinho city, São Paulo state, to control scorpions. The experiences of researchers from the Butantan Institute were also examined (6).

All Regional Offices of Health (ERSAS) were contacted and an intensive training of the collaborating teams was carried on, including lectures and visits to the Institute. A manual describing the procedures of scorpion control was distributed (7). The training was repeated six months later. After this period, a new method was adopted and the Institute technicians started visiting regional health departments. The immediate results of such measure are displayed in Table 1.

\section{RESULTS}

Although the participation was small in the beginning - except for Americana and Ribeirão Preto (the latter was already collaborating before the campaign) - the results started to be noted. During the following year, other eight cities were contributing. The trained personnel from regional health departments were also indirectly disseminating the campaign to several localities, such as Jaboticabal and São José do Rio Preto. Furthermore, more cities started to take part independently, such as Ituiutaba in Minas Gerais state.

A central role was played by the population that lived in regions where scorpions were common. They informed city authorities about the occurrence of animals and due to the previous trainings, municipal employees started to capture live scorpions instead of killing them with pesticides.

However, after sixteen years, only six cities are still sending scorpions regularly: Americana, Limeira, Piracicaba, Presidente Prudente, Ribeirão Preto and São Bernardo do Campo. Therefore, the contact with collaborating organizations must be constantly remembered in order to ensure a regular supply.

It should be noted that the encouragement for scorpion capture depends, essentially, on the presence of trained and motivated staff. For instance, the Municipal Secretary of Health of Americana keeps a regular program to locate and capture scorpions around the city. According to the veterinarian José Brites, who works in the city hall since 1994, the technicians utilize ultraviolet light that facilitate the location of scorpions during the night. Under this light, they become fluorescent and can be easily captured. After the collection, animals are kept and fed live cockroaches. This procedure guarantees a longer lifespan of scorpions, which are regularly sent to the Butantan Institute (an average of 2.500 scorpions per year).

Similarly, Itu has a very dynamic Zoonosis Control Center, which sustained the activities developed by Rene D'Avila related to poisonous animals, including capture of snakes, spiders and scorpions. The city employs a biologist, who trains the inhabitants to avoid accidents and to inform the city administration about the occurrence of scorpions.

\section{FINAL REMARKS}

- The regular production of anti-scorpion serum depends on strategies developed by the Butantan Institute to obtain live animals.

- Such strategies must be constantly reviewed and reinforced.

- The current strategy ensures the necessary supply of scorpions and relies on the collaboration of city authorities, population and motivated city workers.

\section{ACKNOWLEDGEMENTS}

We would like to thank Rafael Braga (University of São Paulo) for the elaboration of the table and Camila Huffenbaecher for the helpful suggestions and revision of English language. 


\section{COPYRIGHT}

(C) CEVAP 2010

\section{SUBMISSION STATUS}

Received: August 18, 2010.

Accepted: August 18, 2010.

Full paper published online: November 30, 2010.

\section{CONFLICTS OF INTEREST}

There is no conflict.

\section{CORRESPONDENCE TO}

SYLVIA MARLENE LUCAS, Laboratório de Artrópodes, Instituto Butantan, Avenida Vital Brazil, 1500, São Paulo, SP, Brasil. Phone: +55 11 37267222 2066. Email: sylvialucas@butantan.gov.br.

\section{REFERENCES}

1. Brazil V. Soro anti-escorpiônico. Nota apresentada à Segunda Conferência da Sociedade Sulamericana de Higiene, Microbiologia e Patologia. Mem Inst Butantan. 1918;1(1);47-52.

2. Lucas SM. O laboratório de artrópodes do Instituto Butantan e os aracnídeos peçonhentos. Hist. cienc. saude-Manguinhos. 2003;10(3):1025-35.
3. Bücherl W. Escorpiões e escorpionismo - 1 . Manutenção dos escorpiões em viveiros e extração do veneno. Mem Inst Butantan.1952;25(1):53-82.

4. Eickstedt VRD von, Ribeiro LA, Candido DM, Albuquerque MJ, Jorge MT. Evolution of scorpionism by Tityus bahiensis (Perty) and Tityus serrulatus (Lutz and Mello) and geographical distribution of the two species in the state of São Paulo, Brazil. J Venom Anim Toxins. 1996;2(2):92-105.

5. Lourenço WR, Cloudsley-Thompson JL, Cuellar O, Eickstedt VRD von, Barraviera B, Knox MB. The evolution of scorpionism in Brazil in recent years. J Venom Anim Toxins. 1996;2(2):121-34.

6. Taveira. LA, Ferreira CS, Carvalho ME, Eickstedt VRD von, Rodrigues FE, Dal Fabbro AL. Escorpionismo no município de Sertãozinho, São Paulo. Mem Inst Butantan. 1990;52(supl 37):804.

7. São Paulo. Secretaria de Estado da Saúde de São Paulo. Manual de Diretrizes para Atividades de Controle de Escorpiões. São Paulo: Secretaria de Estado da Saúde de São Paulo; 1994. p. 48. 